\title{
PERSEPSI PETANI TERHADAP TEKNOLOGI SISTEM TANAM JAJAR LEGOWO PADI SAWAH (Oryza sativa L) DI DESA TAMANMARTANI KECAMATAN KALASAN KABUPATEN SLEMAN
}

\author{
Wahjuni, Agus Wartapa, dan Sukadi \\ Politeknik Pembangunan Pertanian Yogyakarta-Magelang \\ J1. Kusumanegara No.2, Yogyakarta, 55167 \\ Email : Wahjuni099@hmail.com
}

\begin{abstract}
Tamanmartani is a government program that is the integrated crop planting movement (GPPTT) program in the year 2015. One of the components is rice planting with Legowo and planting system. But farmers until now still apply floor tile system. That the impact on the average productivity in Tamanmartani Village 5 last year only reached 5 ton/ha, from the year 2014-2018. This study was conducted from January to July 2019, in Tamanmartani village, Kalasan District, Sleman Regency. The method used is descriptive, data collection using interviews, questionnaires, and observations using a Likert scale with precise, less precise, and incorrect categories. Respondents were determined by Proportionate Random Sampling as many as 39 farmers who participated in the program (GP-PTT). Results showed that the analysis of the perception of farmers from 4 variables on knowledge, interests, attitudes, and needs, turns out the lowest variable with a percentage of 67.09 that is the attitude variable, with the lower statement The "Implementation of tajarwo system" with a percentage of $58.97 \%$. This means that the attitude of farmers has a negative affects on farmers "perception of technology in the Legowo farming system.
\end{abstract}

Keywords : Farmer perception, Technology, Jajar Legowo, Rice paddy fields.

\section{PENDAHULUAN}

Sektor pertanian utamanya komoditas padi sampai saat ini masih merupakan komoditas yang sangat strategis. Sebagai bahan penghasil beras dan dimanfaatkan sebagai pangan sebagian besar masyarakat Indonesia. Produksi padi terkait dengan banyak faktor salah satunya adalah penerapan tenik budidaya padi. Teknik budidaya yang tepat dan sesuai dengan lingkungan tumbuh dapat menjadi penentu keberhasilan pertanaman padi. Salah satu yang menyebabkan pengelolaan tanaman berhasil dipengaruhi oleh ketersediaan dan kemampuan tanaman dalam memanfaatkan sumberdaya lingkungan tumbuh tanaman (Abdul, 2013).

Permintaan padi (beras) terus meningkat seiring dengan laju pertambahan penduduk.
Laju pertumbuhan jumlah penduduk masih lebih tinggi bila dibandingkan dengan laju pertumbuhan produksi padi nasional, di sisi lain luas baku lahan sawah dan kualitasnya cenderung menurun akibat konversi lahan dan faktor faktor lainnya. Oleh karena upaya peningkatan produksi padi harus terus dilakukan melalui berbagai terobosan peningkatan produksi dan produktivitas (Kementan, 2016).

Program pertanian yang telah sampai ke pemerintah daerah di setiap kabupaten seperti Kabupaten Sleman adalah program peningkatan produksi, produktivitas dan mutu hasil produksi tanaman pangan. Peningkatan produksi dan produktivitas tanaman pangan yang dilakukan dengan kegiatan pengelolalan tanaman terpadu (PTT) padi. Pengelolaan tanaman terpadu 
padi yang disampaikan dengan program Gerakan Penerapan Pengelolaan Tanaman Terpadu (GP-TT). Kegiatan GP-PTT peserta belajar langsung di lapangan melalui pembelajaran dan penghayatan langsung (mengalami), mengungkapkan, menganalisis, menyimpulkan serta menerapkan, menghadapi dan memecahkan masalah dalam teknik budidaya. GP-PTT yang dilakukan merupakan teknologi dianjurkan pemerintah untuk diterapkan oleh petani seluruh Indonesia.

Produktivitas padi sawah di Kabupaten Sleman, Kecamatan Kalasan, Desa Tamanmartani dari data Statistik pada tahun 2014 sampai tahun 2018 terlihat produktivitas pada tahun 2014 ( 5,71 ton/ ha) sampai 2015 (5,16 ton/ha) mengalami penurunan, dan pada tahun 2016 (5,96 ton/ ha) mengalami peningkatan hampir mencapai 6 ton/ha, namun pada tahun 2017 sampai 2018 mengalami penurunan produktivitas yaitu 5,023 Ton/ha. (BPS Kabupaten Sleman, 2015).

Kecamatan Kalasan merupakan wilayah administratif di Kabupaten Sleman Propinsi DIY, ikut andil dalam program peningkatan produktivitas tanaman pangan, khususnya padi. Kecamatan Kalasan dengan luas keseluruhan wilayah 3.579 ha, terdiri dari 4 Desa yaitu Desa Purwomartani, Desa Selomartani, Desa Tamanmartani, dan Desa Tirtomartani. Desa Tamanmartani luas wilayahnya 784 ha dengan penggunaan lahan pertanian paling banyak untuk sawah 381 ha untuk pemukiman 84 ha, untuk perkebunan 10 ha, untuk kuburan 4 ha, untuk pekarangan 36 ha, untuk taman dan perkantoran 3 ha, dan untuk prasarana umum lainnya 220 ha.
Desa Tamanmartani melaksanakan GPPTT pada tahun 2015. Komponen PTT salah satunya adalah pengaturan pola jarak tanam yang diterapkan sistem tanam jajar legowo. Namun keadaan di lapangan petani tidak mau menerapkan sistem tanam jajar legowo pada lahan usaha tani nya, sehingga pada kenyataannya saat ini petani kembali menerapkan sistem tanam tegel, penerapan sistem tanam jajar legowo diterapkan hanya pada saat ada kegiatan GP-PTT saja (Programa Kecamatan Kalasan 2018). Perlu adanya penyuluhan sebagai penyemangat dan membangun persepsi petani agar mau menerapkan tanam jajar legowo pada padi sawahnya, sehingga petani tidak salah persepsi mengenai sistem tanam jajar legowo.

Inovasi sistem jajar legowo sudah cukup lama di deseminasikan tetapi sampai saat ini penerapannya masih rendah. Inovasi tanam jajar legowo tidak diterapkan dengan baik di Desa Tamanmartani, maka berdampak pada penurunan produktivitas pada tanaman padi. Tanam jajar legowo merupakan bagian dari pengendalian hama dan penyakit seperti penyakit kresek dan hawar daun bakteri pada tanaman padi. Teknik penerapan tanam jajar legowo yaitu tanaman yang berselang seling dan ada ruang kosong maka cahaya akan mudah masuk pada setiap rumpun padi. Tanaman yang memperoleh sinar matahari yang cukup banyak, sehingga menghindarkan dari kelembaban yang tinggi. Penerapan yang rendah tanam jajar legowo perlu kajian untuk mengetahui persepsi petani di Desa Tamanmartani terhadap inovasi teknologi sistem tanam jajar legowo, dan sejauh mana dapat diterima masyarakat petani di Desa Tamanmartani Kecamatan Kalasan, serta 
permasalahan yang menyebabkan inovasi ini belum begitu berkembang dengan baik.

Salah satu upaya untuk meningkatkan hasil produksi pertanian serta pendapatan petani adalah dengan menerapkan sistem teknologi tajarwo dalam usaha pertanian. Namun hasil observasi awal memperlihatkan masih banyak petani di Desa Tamanmartani, Kecamatan Kalasan, Kabupaten Sleman yang masih belum menerapkan sistem teknologi tajarwo pada usahatani padi sawah. Padahal sudah banyak petani yang mengetahui sistem teknologi tajarwo. Banyaknya petani yang belum menerapkan sistem teknologi tajarwo karena persepsi petani belum tepat untuk menerapkan sistem teknologi tajarwo, sehingga produktifitasnya rendah, Petani menganggap bahwa sistem tajarwo terlalu rumit, Oleh karena itu perlu dikaji tentang persepsi petani terhadap teknologi sistem tanam jajar legowo padi sawah di Desa Tamanmartani Kecamatan Kalasan.

\section{TINJAUAN PUSTAKA}

\section{Teori Persepsi.}

Persepsi merupakan suatu proses yang didahului oleh penginderaan. Penginderaan adalah merupakan suatu proses diterimanya stimulus oleh individu melalui alat penerima yaitu indra namun proses tersebut tidak berhenti disitu saja, pada umumnya stimulus tersebut tersebut diteruskan oleh syaraf ke otak sebagai pusat susunan syaraf, dan proses selanjutnya merupakan merupakan proses persepsi. Karena itu proses persepsi tidak dapat terlepas dari proses pengindraan, dan proses penginderaan merupakan proses yang mendahului terjadinya persepsi. Proses penginderaan terjadi setiap saat, yaitu pada waktu individu menerima stimulus yang mengenai dirinya melalui indera. Alat indera merupakan penghubung antara individu dengan dunia luarnya (Branca, 1964; Woodworth dan Marquis, 1957) dalam (Walgito, 1978 )

\section{A. Aspek aspek Persepsi}

Pada hakekatnya sikap adalah merupakan suatu interelasi dari berbagai komponen, dimana komponen-komponen tersebut menurut Allport (2009), dalam Gazali (2018), ada tiga yaitu:

1. Komponen kognitif

Yaitu komponen yang tersusun atas dasar pengetahuan atau informasi yang dimiliki seseorang tentang obyek sikapnya. Dari pengetahuan ini kemudian akan terbentuk suatu keyakinan tertentu tentang obyek sikap tersebut.

\section{Komponen Afektif}

Afektif berhubungan dengan rasa senang dan tidak senang. Jadi sifatnya evaluatif yang berhubungan erat dengan nilai-nilai kebudayaan atau sistem nilai yang dimilikinya.

3. Komponen Konatif

Yaitu merupakan kesiapan seseorang untuk bertingkah laku yang berhubungan dengan obyek sikapnya.

Jalaludin Rakhmat, (2018) Persepsi adalah pengalaman, tentang objek, peristiwa, atau hubungan-hubungan yang diperoleh dengan menyimpulkan informasi dan menafsirkan pesan. Persepsi ialah memberikan makna pada stimulus indrawi (sensory stimuli).

Hubungan sensasi dengan persepsi sudah jelas. Sensasi adalah bagian dari 
persepsi. Walaupun begitu, menafsirkan makna informasi indrawi tidak hanya melibatkan sensasi, tetapi juga atensi, ekspektasi, motivasi, dan memori(Desiderato, 1976:129) dalam (Jalaludin Rakhmat, 2018).

Persepsi merupakan aktivitas yang intergrated dalam diri individu, maka apa yang ada dalam diri individu akan ikut aktif dalam persepsi. Berdasarkan hal tersebut, maka dalam persepsi dapat dikemukakan karena perasaan, kemampuan berpikir berpikir, pengalaman-pengalaman individu tidak sama, maka dalam mempersepsikan sesuatu stimulus, hasil persepsi mungkin akan berbeda antara individu satu dengan individu lain. Persepsi itu bersifat individual. (Davidoff, 1981; Rogers, 1956) dalam (Bimo Walgito, 2005)

Persepsi adalah pengalaman tentang obyek, peristiwa atau hubungan-hubungan yang diperoleh dengan menyimpulkan informasi dan menafsirkan pesan. Persepsi ialah memeberikan makna kepada stimulus inderawi. MenurutLuthans, persepsiituadalah lebih kompleks dan luas kalau dibandingkan dengan penginderaan. Walaupun persepsi sangat tergantung pada penginderaan data, proses kognitif barangkali bisa menyaring, menyederhanakan, atau mengubah secara sempurna data tersebut. Dengan kata lain proses persepsi dapat menambah, dan mengurangi kejadian kenyataannya yang diinderakan oleh seseorang (Miftah Thoha, 1983:40) dalam (Purwatiningsih, 2008)

Schermerhorn, (2005) dalam Simbolon, (2008) perception is the process by which people select, organize, interpret, retrieve and respond to information from the world around them. Persepsi adalah proses dimana orang-orang memilih, mengorganisir, menginterpretasikan, mendapat kembali dan merespon terhadap informasi dari dunia di sekitarnya. Dengan kata lain persepsi berkaitan dengan bagaimana seseorang dapat menginterpretasikan dan merespon informasi yang berasal dari luar.

Notoatmodjo (2010) dalam Sari (2015) persepsi adalah pengalaman tentang objek, peristiwa atau hubungan-hubungan yang diperoleh dengan menyimpulkan informasi dan menafsirkannya. Menurut Walgito, (1978) persepsi merupakan suatu proses yang didahulu oleh proses pengindraan, yaitu merupakan proses diterimanya stimulus oleh individu melalui alat indera atau juga disebut proses sensoris. Sari, (2015) berpendapat bahwa persepsi biasanya untuk mengungkapkan tentang pengalaman terhadap suatu benda atau kejadian.

B. Faktor - faktor yang berperan dalam persepsi adalah :

1. Objek yang dipersepsi

Objek menimbulkan stimulus yang mengenai alat indera atau reseptor. Stimulus dapat datang dari luar individu yang mempersepsi, tetapi juga dapat datang dari dalam diri individu yang bersangkutan yang langsung mengenai syaraf penerima yang bekerja sebagai reseptor.

2. Alat indera, syaraf, dan pusat susunan syaraf

Alat indera atau reseptor merupakan alat untuk menerima stimulus. Disamping itu juga harus ada syaraf sensoris sebagai alat untuk meneruskan stimulus yang diterima reseptor ke pusat susunan syaraf, yaitu otak sebagai pusat kesadaran. 
3. Perhatian

Perhatian merupakan pemusatan atau konsentrasi dari seluruh aktivitas individu yang ditujukan kepada sesuatu atau sekumpulan objek.

C. Faktor-faktor yang Berpengaruh pada Persepsi :

Walgito (1978), menegaskan bahwa apa yang ada dalam diri individu akan mempengaruhi dalam individu mengadakan persepsi, ini merupakan faktor internal. Disamping itu masih ada faktor lain yang dapat mempengaruhi dalam dalam proses persepsi, yaitu stimulus itu sendiri dan faktor lingkungan di mana persepsi itu berlangsung, dan ini merupakan faktor eksternal. Stimulus dan lingkungan sebagai faktor eksternal dan individu sebagai faktor internal saling berinteraksi dalam individu mengadakan persepsi.

Persepsi ditentukan oleh faktor personal dan faktor situasional (Rakhmat, 2005). David Krech dan Richard S. Cruthfield (1997) dalam Arifin et al (2017) menyebutnya faktor fungsional dan faktor struktural. Adapun penjelasannya adalah sebagai berikut: Faktor Fungsional: Faktor fungsional berasal dari kebutuhan, pengalaman masa lalu dan halhal lain yang termasuk dalam faktor-faktor personal. Persepsi tidak ditentukan oleh jenis atau bentuk stimuli, tetapi karakteristik orang yang memberikan respon pada stimuli tersebut. Faktor Struktural: Faktor struktural berasal dari sifat stimuli fisik dan efek-efek saraf yang ditimbulkannya pada sistem saraf individu.

Gibson(1998), dalam Simbolon,(2008), menyatakan bahwa persepsi dipengaruhi oleh berbagai faktor, antara lain faktor belajar, motivasi, dan pemerhati perseptor atau pemersepsi ketika proses persepsi terjadi. Dan karena ada beberapa faktor yang bersifat yang bersifat subyektif yang mempengaruhi, maka kesan yang diperoleh masing-masing individu akan berbeda satu samalain. Persepsi individu dipengaruhi oleh faktor fungsional dan struktural.Faktor fungsional ialah faktorfaktor yang bersifat personal. Misalnya kebutuhan individu, usia, pengalaman masa lalu, kepribadian,jenis kelamin, dan hal-hal lain yang bersifat subjektif. Faktor struktural adalah faktor di luar individu, misalnya lingkungan, budaya, dan norma sosial sangat berpengaruh terhadap seseorang dalam mempresepsikan sesuatu (Anshari, 2013).

Menurut Toha (2003) dalam Arifin et al. (2017), faktor-faktor yang mempengaruhi persepsi seseorang adalah sebagai berikut:

1. Faktor internal: perasaan, sikap dan karakteristik individu, prasangka, keinginan atau harapan, perhatian (fokus), proses belajar, keadaan fisik, gangguan kejiwaan, nilai dan kebutuhan juga minat, dan motivasi.

2. Faktor eksternal: latar belakang keluarga, informasi yang diperoleh, pengetahuan dan kebutuhan sekitar, intensitas, ukuran, keberlawanan, pengulangan gerak, halhal baru dan familiar atau ketidak asingan suatu objek.

\section{Tanam Jajar Legowo}

Kementerian Pertanian, (2013) sistem tanam jajar legowo adalah pola bertanam yang berselang-seling antara dua atau lebih (biasanya dua atau empat) baris tanaman padi dan satu baris kosong. Istilah Legowo 
di ambil dari bahasa jawa, yaitu berasal dari kata "lego" berarti luas dan "dowo" berarti memanjang. Legowo di artikan pula sebagai cara tanam padi sawah yang memiliki beberapa barisan dan diselingi satu barisan kosong. Baris tanaman (dua atau lebih) dan baris kosongnya (setengah lebar di kanan dan di kirinya) disebut satu unit legowo. Bila terdapat dua baris tanam per unit legowo maka disebut legowo 2:1, sementara jika empat baris tanam per unit legowo disebut legowo 4:1, dan seterusnya. Pada awalnya tanam jajar legowo umum diterapkan untuk daerah yang banyak serangan hama dan penyakit, atau kemungkinan terjadinya keracunan besi. Jarak tanam dua baris terpinggir pada tiap unit legowo lebih rapat dari pada baris yang ditengah (setengah jarak tanam baris yang di tengah), dengan maksud untuk mengkompensasi populasi tanaman pada baris yang dikosongkan. Pada baris kosong, di antara unit legowo, dapat dibuat parit dangkal. Parit dapat berfungsi untuk mengumpulkan keong mas, menekan tingkat keracunan besi pada tanaman padi atau untuk pemeliharaan ikan kecil (muda). Sistem tanam legowo kemudian berkembang untuk mendapatkan hasil panen yang lebih tinggi dibanding sistem tegel melalui penambahan populasi. Selain itu juga mempermudah pada saat pengendalian hama, penyakit, gulma, dan juga pada saat pemupukan. Pada penerapannya, perlu diperhatikan tingkat kesuburan tanah pada areal yang akan ditanami. Jika tergolong subur, maka disarankan untuk menerapkan pola tanaman sisipan hanya pada baris pinggir (legowo tipe 2). Hal ini dilakukan untuk mencegah kerebahan tanaman akibat serapan hara yang tinggi. Sedangkan pada areal yang kurang subur, maka tanaman sisipan dapat dilakukan pada seluruh barisan tanaman, baik baris pinggir maupun tengah (legowo tipe 1). Saat ini, sistem logowo sudah mulai banyak di adopsi oleh petani di Indonesia. Banyak petani yang sudah merasakan manfaat dan keuntungannya dengan menggunakan teknik tersebut. Dengan sistem tanam legowo, populasi tanaman dapat ditingkatkan yang pada gilirannya diperoleh peningkatan hasil gabah. Menurut Kementerian Pertanian, (2015) faktor lingkungan yang sangat berpengaruh terutama adalah kelembapan yang tinggi sangat memacu perkembangan penyakit kresek dan hawar daun. Bila serangan terjadi saat berbunga, proses pengisian gabah terjadi tidak sempurna, menyebabkan gabah tidak terisi penuh atau bahkan hampa. Pada kondisi ini kehilangan hasil mencapai 50 $70 \%$. Tanam jajar legowo dianggap sangat penting karena tidak hanya meningkatkan produktivitas tetapi juga mempertahankan produktivitas dari serangan hama dan penyakit. Dengan diterapkan tanam jajar legowo secara terus menerus pada tanaman padi sawah di Desa Tamanmartani.

A. Prinsip Tanam Jajar Legowo

Tanam jajar legowo adalah suatu rekayasa teknologi untuk mendapatkan populasi tanaman lebih dari 160.000 per hektar. Penerapan tanam jajar legowo selain meningkatkan populasi pertanaman, juga mampu menambah kelancaran sirkulasi sinar matahari dan udara disekeliling tanaman pingir sehingga tanaman dapat berfotosintesis lebih baik. Tanaman yang berada di pinggir diharapkan memberikan produksi yang lebih tinggi dan kualitas gabah yang lebih baik. 
Tanam jajar legowo terdapat ruang terbuka seluas $25-50 \%$, sehingga tanaman dapat menerima sinar matahari secara optimal yang berguna dalam proses fotosintesis. Penerapan sistem tanam legowo disarankan menggunakan jarak tanam $(25 \times 25) \mathrm{cm}$ antar rumpun dalam baris; $12,5 \mathrm{~cm}$ jarak dalam baris; dan $50 \mathrm{~cm}$ sebagai jarak antar barisan/lorong atau ditulis $(25 \times 12,5 \times 50)$ $\mathrm{cm}$. Hindarkan penggunaan jarak tanam yang sangat rapat, misalnya $(20 \times 20) \mathrm{cm}$, akan menyebabkan jarak dalam baris sangat sempit.

\section{Legowo 2:1}

Sistem tanam legowo 2:1 akan menghasilkan jumlah populasi tanaman per ha sebanyak 213.300 rumpun, serta akan meningkatkan populasi 33,31\% dibanding pola tanam tegel $(25 \times 25) \mathrm{cm}$ yang hanya 160.000 rumpun/ha. Dengan pola tanam ini, seluruh barisan tanaman akan mendapat tanaman sisipan.
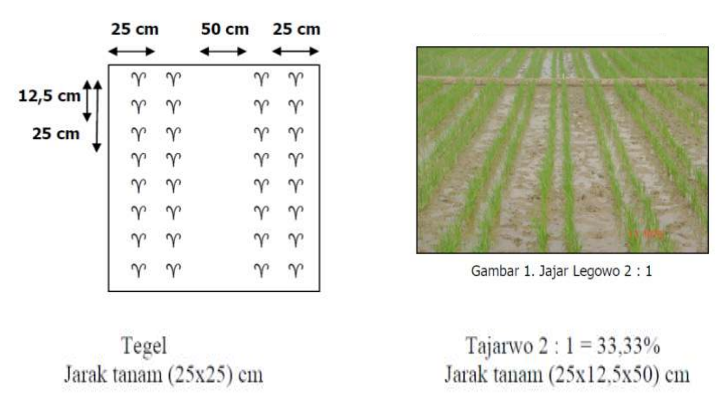
Jarak tanam $(25 \times 12,5 \times 50) \mathrm{cm}$
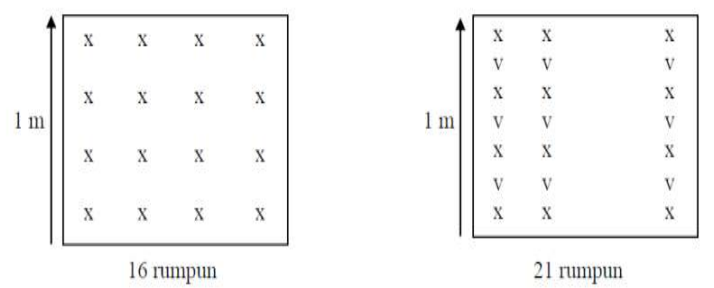

Gambar 1. Pola Tanam Tegel dan Tanam Jajar Legowo $2: 1$

2. Legowo 4:1

Tipe 1

Sistem tanam legowo 4:1 tipe 1 merupakan pola tanam jajar legowo dengan keseluruhan baris mendapat tanaman sisipan. Pola ini cocok diterapkan pada kondisi lahan yang kurang subur. Dengan pola ini, populasi tanaman mencapai 256.000 rumpun/ha dengan peningkatan populasi sebesar $60 \%$ dibanding pola tegel $(25 \times 25) \mathrm{cm}$

Tipe 2

Sistem tanam legowo 4:1 tipe 2 merupakan pola tanam dengan hanya memberikan tambahan tanaman sisipan pada kedua barisan tanaman pinggir. Populasi tanaman 192.712 \pm 4260 rumpun/ ha dengan persentase peningkatan hanya sebesar 20,44\% dibanding pola tegel $(25 \times 25) \mathrm{cm}$. Pola ini cocok diterapkan pada lokasi dengan tingkat kesuburan tanah yang tinggi. Meskipun penyerapan hara oleh tanaman lebih banyak, tetapi karena tanaman lebih kokoh sehingga mampu meminimalkan resiko kerebahan selama pertumbuhan

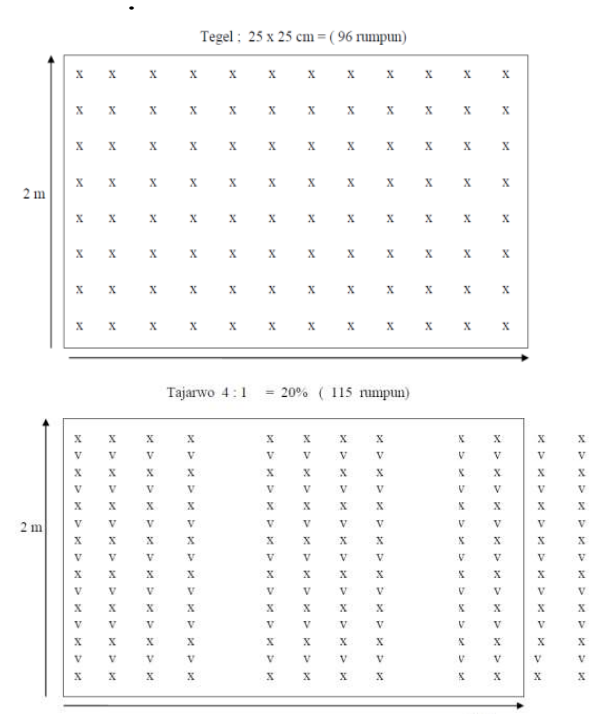

Gambar 2. Pola Tanam Tegel dan Tanam Jajar Legowo $4: 1$

B. Keuntungan Cara Tanam Jajar Legowo

1. Memanfaatkan sinar matahari bagi 
tanaman yang berada pada bagian pinggir barisan. Semakin banyak sinar matahari yang mengenai tanaman, maka proses fotosintesis oleh daun tanaman akan semakin tinggi sehingga akan mendapatkan bobot buah yang lebih berat.

2. Mengurangi kemungkinan serangan hama, terutama tikus. Pada lahan yang relatif terbuka, hama tikus kurang suka tinggal di dalamnya.

3. Menekan serangan penyakit. Pada lahan yang relatif terbuka, kelembaban akan semakin berkurang, sehingga serangan penyakit juga akan berkurang. Mempermudah pelaksanaan pemupukan dan pengendalian hama/penyakit. Posisi orang yang melaksanakan pemupukan dan pengendalian hama/penyakit bisa leluasa pada barisan kosong di antara 2 barisan legowo.

4. Menambah populasi tanaman. Misal pada legowo $2: 1$, populasi tanaman akan bertambah sekitar $30 \%$. Bertambahnya populasi tanaman akan memberikan harapan peningkatan produktivitas hasil.

5. Meningkatkan produktivitas padi 12$22 \%$.

6. Sistem tanam berbaris ini juga berpeluang bagi pengembangan sistem produksi padi-ikan (mina padi) atau prabelek (kombinasi padi, ikan dan bebek). Kementeri pertanian (2013).

C. Kelemahan Sistim Tanam Jajar Legowo

Menurut Ikhwani et al (2013), kelemahan sistem tanam jajar legowo ada 3 aspek sebagai berikut :

1. Aspek Fisiologi

Kelemahan tanam rapat, termasukjajar legowo, adalah senyawa fenolat yang bersifat allelopati dalam jerami dan akar tanaman, yang berpotensi menjadi penghambat pertumbuhan tanaman pada jarak tanam rapat, maupun residunya bagi pertanaman berikutnya.

2. Aspek Agronomis

- Membutuhkan tenaga tanam yang lebih banyak dan waktu tanam yang lebih lama.

- Membutuhkan benih yang lebih banyak dengan semakin banyaknya populasi.

- Biasanya pada bagian lahan yang kososng diantara barisan tanaman akan lebih banyak ditumbuhi rumput.

3. Aspek Sosial - Ekonomis

Apabila menggunakan tenaga manusia, cara tanam jajar legowo memerlukan waktu lebih lama dibandingkan dengan tanam cara tegel, minimal 1,5 kali. Hal ini disebabkan oleh banyaknya benih yang harus ditanam atau spot yang harus ditanami pada cara jajar legowo.

\section{METODE KAJIAN}

\section{Waktu dan Tempat}

Kajian ini telah dilaksanakan pada bulan Januari s/d Juli 2019 di Desa Tamanmartani, Kecamatan Kalasan, Kabupaten Sleman.

\section{Metode Penelitian}

Kajian ini menggunakan metode 
deskriptif yaitu suatu metode dalam meneliti status kelompok manusia, suatu objek, suatu kondisi, suatu sistem pemikiran, ataupun suatu kelas peristiwa pada masa sekarang atau sekurangkurangnya jangka waktu yang masih terjangkau dengan ingatan responden. Tujuan dari penelitian deskriptif ini adalah untuk membuat deskripsi, gambaran atau lukisan secara sistimatis, factual dan akurat mengenai fakta-fakta, sifat-sifat, serta hubungan antar fenomena yang diselidiki (Nazir 2014).

\section{Teknik Pengumpulan Data}

Teknik pengumpulan data yang digunakan dalam kajian ini menurut Sugiyono, (2018) dikemukakan bahwa pengumpulan data berdasarkan tekniknya, yaitu melalui wawancara, angket dan observasi

Jenis data yang dikumpulkan dalam penelitian ini adalah data primer dan data sekunder. Cara pengumpulan data primer menggunakan seperangkat daftar pertanyaan (kuesioner) yang telah dipersiapkan oleh peneliti yang diajukan kepada responden sampel dan wawancara dengan responden dan informan khususnya kepada penyuluh yang bertugas di wilayah tersebut diantaranya mengenai profil wilayah penelitian, kegiatan penyuluhan yang berjalan selama ini, dan permasalahan usahatni yang terjadi di wilayah penelitian.

Data primer yang dikumpulkan adalah: (1) Karakteristik pribadi petani responden yaitu umur, tingkat pendidikan formal dan tingkat pendidikan nonformal; (2) Karakteristik usahatani petani responden yaitu pengalaman berusahatani, luas lahan, status kepemilikan lahan, aksesibilitas pasar dan aksesibilitas saprodi.
Data sekunder yang dikumpulkan berupa keadaan umum wilayah penelitian dan data mengenai kependudukan dari lembaga terkait, yaitu: programa desa/RKPD, Programa Kecamatan 2018, BPP Kecamatan Kalasan yaitu profil kelompok tani, dan BPS Kabupaten Sleman, 2018.

\section{Teknik Pengambilan Sampel}

Populasi dalam kajian ini adalah 7 kelompok tani dari 19 kelompok tani padi sawah di Desa Tamanmartani Kecamatan Kalasan yang sudah mengikuti kegiatan GPTT padi sawah berdasarkan laporan yang ada di BPP Kalasan.

Teknik pengambilan sampel dalam kajian adalah menggunakan teknik purposive random sampling karena pengambilan anggota sampel dari populasi dilakukan secara ditunjuk.

\section{Skala Pengukuran}

Skala Likert yaitu skala yang digunakan untuk mengukur presepsi seseorang atau sekelompok orang tentang fenomena sosial yang selanjutnya disebut variabel penelitian.

\section{Teknik Analisis Data}

Adapun langkah-langkah dalam analisis data untuk menjawab rumusan masalah dalam kajian ini, sebagai berikut:

1. Melakukan rekapitulasi seluruh data yang diperoleh kedalam tabel tabulasi data untuk mengetahui jumlah skor yang diperoleh dari setiap butir instrument;

2. Sugiyono(2018), menyatakanbahwa dalam menentukan skor ideal/kriteriumyaitu skor yang ditetapkan dengan asumsi bahwa setiap responden pada setiap pertanyaan memberi jawaban dengan skor tertinggi., menggunakan rumus menentukan skor ideal, sebagai berikut: Skor ideal $=$ Skor 
tertinggi $\mathrm{x}$ butir instrumen $\mathrm{x}$ responden.

3. Membagi jumlah skor hasil penelitian pada setiap variabel dengan skor ideal untuk mengetahui nilai dari setiap variabel. Adapun rumus yang digunakan untuk mengetahui nilai dari setiap variabel, sebagai berikut:

$$
\text { Nilai Variabel }=\frac{(\Sigma \text { Skor })}{(\text { Skor Ideal })} \times 100
$$

4. Nazir (1988), menjelaskan bahwa analisis data bertujuan untuk merumuskan suatu permasalahan yang tertuang dalam rumusan masalah.Teknik yang digunakan dalam analisis data, yaitu dengan menjumlahkan dan menskor data yang diperoleh dengan langkah-langkah, sebagai berikut:

a. Data dalam bentuk skor dihitung jumlah dan rata-rata skor setiap pertanyaan, skor tiap responden, dan skor komulatif.

b. Nilai skor setiap unsur responden tentang persepsi petani terhadap teknologi sistem jajar legowo diukur dengan Skala Likert yaitu :
1) Tepat
$=\mathrm{a}=3$
2) Kurang tepat
$=\mathrm{b}=2$
3) Tidak tepat
$=\mathrm{c}=1$

c. Pencapaian skor persepsi petani terhadap teknologi sistem tanam jajar legowo pada budidaya padi sawah ditetapkan dengan kategori Tepat, Kurang tepat, dan Tidak tepat. Menetapkan kategori dari setiap nilai veriabel yang diperoleh menjadi 3 kategori dengan menggunakan rumus penentuan interval kelas, sebagai berikut :

$$
\mathbf{I}=\frac{R}{K}
$$

Keterangan :

$\mathrm{I}=$ Interval kelas

$\mathrm{R}=$ Range $\left(\sum\right.$ skor maks $-\sum$ skor minimal)

$\mathrm{K}=$ Jumlah kelas (kategori), sehingga :

$$
I=\frac{100 \%-33,33 \%}{3}=22,22 \%
$$

Nilai maksimal $=3$ (nilai maksimal 100\%) Nilai minimal $=1$ (nilai minimal $33,33 \%$ )

Jumlah kelas $=3$

Keterangan :

Tinggi $=$ Skor capaian 77,77\%-100\%

Sedang = Skor capaian 55,55\%-

$77,76 \%$

Rendah = Skor capaian 33,33\%$55,54 \%$

\section{HASIL DAN PEMBAHASAN}

Hasil kajian yang dilakukan adalah tentang persepsi petani terhadap teknologi sistem tanam jajar legowo padi sawah di Desa Tamanmartani Kecamatan Kalasan Kabupaten Sleman. Dalam pembahasan ini ada empat variable yang akan di bahas berdasarkan hasil olah data dari responden yaitu pengetahuan, Minat, Sikap, Kebutuhan.

\section{A. Komponen Kognitif (Pengetahuan)}

Berdasarkan Tabel 1 menunjukkan bahwa sebanyak 23 petani dengan presentase $58,97 \%$ yang menjawab dengan kategori tepat, sedangkan 13 petani dengan presentase $33,33 \%$ yang menjawab dengan kategori kurang tepat, dan sebanyak 3 petani dengan presentase $7,69 \%$ petani menjawab dengan kategori tidak tepat. Hal ini menunjukan bahwa Komponen pengetahuan petani masih perlu ditingkatkan dengan memberikan edukasi kepada petani tentang teknologi 
sistem tanam jajar legowo, karena sebagian besar persepsi petani terhadap sistem tanam jajar legowo masih kurang tepat, dan bahkan masih ada petani yang berpengetahuan tidak tepat, hal tersebut tentu dapat mempengaruhi persepsi petani terhadap sistem tanam jajar legowo. Persepsi petani yang tepat tentunya dibentuk oleh pengalaman-pengalaman dan pengetahuan petani tentang cara tanam teknologi tajarwo yang tepat dan sesuai rekomendasi. Hasil kajian persepsi petani dari Komponen pengetahuan pada sistem tanam jajar legowo secara lengkap dapat dilihat pada Tabel 1 di bawah ini.

Tabel 1. Distribusi Hasil Tabulasi Komponen Pengetahuan

\begin{tabular}{clcccc}
\hline No & Kategori & Singkatan & Kriteria & Jumlah & Persentase $\%$ \\
\hline 1 & Tepat & T & $77,78-100$ & 23 & 58.97 \\
2 & Kurang Tepat & KT & $55,56-77,77$ & 13 & 33.33 \\
3 & Tidak Tepat & TT & $33,33-55,55$ & 3 & 7.69 \\
\hline & Jumah & & & 39 & 100.00 \\
\hline
\end{tabular}

Sumber : Olah Data Primer 2019

Tabel 2. Capaian Hasil Tabulasi Komponen Pengetahuan

\begin{tabular}{|c|c|c|c|c|c|}
\hline No & Indikator & Skor jumlah & Rerata & Persentase & Kategori \\
\hline 1 & Penyisipan tanaman & 92 & 30.67 & $78.63 \%$ & $\mathrm{~T}$ \\
\hline 2 & Perbandingan populasi & 99 & 33.00 & $84.62 \%$ & $\mathrm{~T}$ \\
\hline 3 & Jarak tanam & 79 & 26.33 & $67.52 \%$ & KT \\
\hline 4 & Lebar lorong & 81 & 27.00 & $69.23 \%$ & KT \\
\hline 5 & Alat-alat yang dipakai & 96 & 32.00 & $82.05 \%$ & $\mathrm{~T}$ \\
\hline 6 & Tingkat kesulitan & 97 & 32.33 & $82.91 \%$ & $\mathrm{~T}$ \\
\hline 7 & peningkatan populasi & 83 & 27.67 & $70.94 \%$ & KT \\
\hline 8 & Pembuatan garis tanam & 97 & 32.33 & $82.91 \%$ & $\mathrm{~T}$ \\
\hline 9 & Teknik Penanaman & 73 & 24.33 & $62.39 \%$ & KT \\
\hline \multirow[t]{3}{*}{10} & Teknik pemupukan & 104 & 34.67 & $88.89 \%$ & $\mathrm{~T}$ \\
\hline & Jumlah & 901 & 300.33 & $770.09 \%$ & \\
\hline & Rerata & 90.1 & 30.03 & $77.01 \%$ & KT \\
\hline
\end{tabular}

Sumber : Olah Data Primer 2019

Berdasarkan Tabel 2 capaian aspek Komponen pengetahuan dapat dilihat bahwa dari beberapa penyataan atau indikator tersebut, ternyata $60 \%$ pertanyaan dijawab dengan Kategori tepat, dan $40 \%$ pertanyaan dijawab dengan kategori kurang tepat. Capaian keseluruhan dari rata-rata Komponen pengetahuan yaitu $77,01 \%$ dengan kategori kurang tepat. Hal ini dipengaruhi oleh karena pengetahuan petani terhadap sistem tanam jajar legowo yang masih rendah, seperti pada peryataan mengenai jarak tanam tajarwo, lebar lorong sistem tanam jajar legowo, peningkatan populasi, dan teknik penanaman sistem tanam jajar legowo. Oleh karena itu perlu adanya dorongan penyuluhan untuk meningkatkan pengetahuan petani agar seluruh petani lebih mengetahui lagi sistem tanam jajar legowo sehingga diharapkan dapat meningkatkan persepsi petani mengenai sistem tanam jajar legowo yang baik dan tepat sesuai rekomendasi yang ada. 


\section{B. Komponen Afektif (Minat)}

Berdasarkan Tabel 3, analisis data kajian menunjukkan sebanyak 28 petani dengan presentase $71,79 \%$ yang menjawab dengan kategori tepat, sedangkan sebanyak 9 petani dengan presentase $23,08 \%$ yang menjawab dengan kategori kurang tepat, dan sebanyak 2 petani dengan presentase 5,13\% yang menjawab dengan kategori tidak tepat. Jika dilihat dari Tabel 4.15 tersebut ternyata minat petani terhadap sistem tanam jajar legowo cukup tinggi dengan kategori tepat sehingga dapat mendorong petani untuk mau menerapkan sistem tajarwo dan diharapkan dapat meningkatkan persepsi petani, meskipun masih ada yang dengan kategori kurang tepat dan bahkan dengan kategori tidak tepat. Hasil kajian persepsi petani dari Komponen minat secara lengkap dapat dilihat pada Tabel 3 di bawah ini.

Tabel 3. Distribusi Hasil Tabulasi Komponen Minat

\begin{tabular}{clcccr}
\hline No & Kategori & Singkatan & Kriteria & Jumlah & Persentase \% \\
\hline 1 & Tepat & T & $77,78-100$ & 28 & 71.79 \\
2 & Kurang Tepat & KT & $55,56-77,77$ & 9 & 23.08 \\
3 & Tidak Tepat & TT & $33,33-55,55$ & 2 & 5.13 \\
\hline & Jumah & & & 39 & 100.00 \\
\hline
\end{tabular}

Sumber : Olah Data Primer 2019

Berdasarkan Tabel 4 capaian aspek Komponen minat dapat dilihat bahwa dari beberapa penyataan atau indikator tersebut, ternyata $62,5 \%$ pertanyaan dijawab dengan Kategori tepat, dan 37,5\% pertanyaan dijawab dengan kategori kurang tepat. Capaian keseluruhan dari rata-rata Komponen minat yaitu 79,59\% dengan kategori tepat. Hal ini menunjukan bahwa petani minat terhadap sistem tanam jajar legowo namun masih perlu ditingkatkan lagi dalam penerapan dilahan oleh petani sehingga dapat meningkatkan produktivitas padi sawah. Oleh karena itu perlu adanya dorongan penyuluhan untuk meningkatkan minat petani supaya persepsi petani terhadap sistem tanam jajar legowo berada pada kategoro sangat tepat sesuai rekomendasi. Hasil tabulasi variavel minat secara lengkap dapat dilihat pada Tabel 4.

Tabel 4. Capaian Hasil Tabulasi Komponen Minat

\begin{tabular}{|c|c|c|c|c|c|}
\hline No & Indikator & Jumlah & Rerata & Presentase & Kategori \\
\hline 1 & Penyisipan tanaman & 95 & 31.67 & $81.20 \%$ & $\mathrm{~T}$ \\
\hline 2 & Lebar lorong & 93 & 31.00 & $79.49 \%$ & $\mathrm{~T}$ \\
\hline 3 & Alat-alat untuk menanam & 91 & 30.33 & $77.78 \%$ & KT \\
\hline 4 & Baris tanam tajarwo & 97 & 32.33 & $82.91 \%$ & $\mathrm{~T}$ \\
\hline 5 & Menanam jajar legowo & 92 & 30.67 & $78.63 \%$ & $\mathrm{~T}$ \\
\hline 6 & Teknik pemupukan tajarwo & 86 & 28.67 & $73.50 \%$ & KT \\
\hline 7 & Cara penyiangan tajarwo & 88 & 29.33 & $75.21 \%$ & KT \\
\hline \multirow[t]{3}{*}{8} & Pengendalian OPT pada tajarwo & 103 & 34.33 & $88.03 \%$ & $\mathrm{~T}$ \\
\hline & Jumlah & 745 & 248.33 & $636.75 \%$ & \\
\hline & Rerata & 74.5 & 24.83 & $79.59 \%$ & $\mathrm{~T}$ \\
\hline
\end{tabular}

Sumber : Olah Data Primer 2019 


\section{Komponen Konatif (Sikap)}

Berdasarkan Tabel 5, analisis data kajian menunjukkan sebanyak 8 petani dengan presentase 20,51\% yang menjawab dengan kategori tepat, sedangkan sebanyak 25 petani dengan presentase $64,10 \%$ yang menjawab dengan kategori kurang tepat, dan sebanyak 6 petani dengan presentase $15,38 \%$ yang menjawab dengan kategori tidak tepat.
Jika dilihat dari Tabel 5 tersebut ternyata sikap petani terhadap sistem tanam jajar legowo perlu adanya dorongan yang kuat untuk membentuk sikap petani agar lebih meningkat untuk mencapai sikap dengan kategori tepat. Hasil kajian persepsi petani dari Komponen Sikap pada sistem tanam jajar legowo secara lengkap dapat dilihat pada Tabel 5.

Tabel 5. Distribusi Hasil Tabulasi Komponen Sikap

\begin{tabular}{clcccc}
\hline No & Kategori & Singkatan & Kriteria & Jumlah & Persentase \% \\
\hline 1 & Tepat & T & $77,78-100$ & 8 & 20.51 \\
2 & Kurang Tepat & KT & $55,56-77,77$ & 25 & 64.10 \\
3 & Tidak Tepat & TT & $33,33-55,55$ & 6 & 15.38 \\
\hline & Jumah & & & 39 & 100.00 \\
\hline
\end{tabular}

Sumber : Olah Data Primer 2019

Berdasarkan Tabel 6 capaian aspek Komponen sikap dapat dilihat bahwa dari beberapa

penyataan atau indikator tersebut, ternyata $100 \%$ pertanyaan dijawab dengan Kategori kurang tepat, dengan Capaian keseluruhan dari rata-rata Komponen minat yaitu 67,09\% dengan kategori kurang tepat. Hal ini menunjukan bahwa sikap petani terhadap sistem tanam jajar legowo masih jauh kurang baik, oleh karena itu perlu ditingkatkan dengan dilakukan penyuluhan yang berkelanjutan sehingga dapat mendorong sikap dan meningkatkan persepsi petani terhadap sistem tanam jajar legowo pada kategoro sangat tepat sesuai rekomendasi.

Tabel 6. Capaian Hasil Tabulasi Komponen Sikap

\begin{tabular}{clcccc}
\hline No & Indikator & Jumlah & Rerata & Persentase & Kategori \\
\hline 1 & Penyisipan tanaman & 83 & 27.67 & $70.94 \%$ & KT \\
2 & Jarak tanam & 73 & 24.33 & $62.39 \%$ & KT \\
3 & Lebar lorong & 76 & 25.33 & $64.96 \%$ & KT \\
4 & Alat-alat menanam & 78 & 26.00 & $66.67 \%$ & KT \\
5 & Kesulitan penanaman & 71 & 23.67 & $60.68 \%$ & KT \\
6 & Penanaman tajarwo & 69 & 23.00 & $58.97 \%$ & KT \\
7 & Teknik penanaman & 82 & 27.33 & $70.09 \%$ & KT \\
8 & Teknik pemupukan & 85 & 28.33 & $72.65 \%$ & KT \\
9 & penyiangan tajarwo & 82 & 27.33 & $70.09 \%$ & KT \\
10 & Pengendalian OPT & 86 & 28.67 & $73.50 \%$ & KT \\
\hline & Jumlah & 785 & 261.67 & $670.94 \%$ & \\
\hline & Rerata & 78.5 & 26.17 & $67.09 \%$ & KT \\
\hline
\end{tabular}

Sumber : Olah Data Primer 2019 


\section{Komponen Kebutuhan}

Berdasarkan Tabel 7, analisis data kajian menunjukkan sebanyak 25 petani dengan presentase $64,10 \%$ yang menjawab dengan kategori tepat, sedangkan sebanyak 11 petani dengan presentase $28,21 \%$ yang menjawab dengan kategori kurang tepat, dan sebanyak 3 petani dengan presentase $7,69 \%$ yang menjawab dengan kategori tidak tepat. Jika dilihat dari Tabel 4.19 tersebut ternyata kebutuhan petani terhadap sistem tanam jajar legowo dikategorikan cukup baik karena sebagian besar dari pernyataan tersebut petani sudah menjawab dengan kategori tepat, meskipun masih ada pernyataan dengan kategori kurang tepat dan bahkan tidak tepat. Untuk itu perlu adanya dorongan yang berkelanjutan untuk meningkat persepsi petani terhadap sistem tanam jajar legowo padi sawah. Hasil kajian persepsi petani dari Komponen kebutuhan pada sistem tanam jajar legowo secara lengkap dapat dilihat pada Tabel 7 di bawah ini.

Tabel 7. Distribusi Hasil Tabulasi Komponen Kebutuhan

\begin{tabular}{llcccc}
\hline No & Kategori & Singkatan & Kriteria & Jumlah & Persentase \% \\
\hline 1 & Tepat & T & $77,78-100$ & 25 & 64.10 \\
2 & Kurang Tepat & KT & $55,56-77,77$ & 11 & 28.21 \\
3 & Tidak Tepat & TT & $33,33-55,55$ & 3 & 7.69 \\
\hline & Jumah & & & 39 & 100.00
\end{tabular}

Sumber : Olah Data Primer 2019

Tabel 8. Capaian Hasil Tabulasi Komponen Kebutuhan

\begin{tabular}{llcccc}
\hline No & \multicolumn{1}{c}{ Indikator } & Jumlah & Rerata & Persentase & Kategori \\
\hline $1 \quad \begin{array}{l}\text { Kebutuhan dalam peningkatan produktivitas? } \\
2\end{array}$ & 94 & 31.33 & $80.34 \%$ & $\mathrm{~T}$ \\
$\quad \begin{array}{l}\text { Mengiginkan sistem tajarwo karena dapat meningkatkan } \\
\text { bobot padi lebih berat? }\end{array}$ & 94 & 31.33 & $80.34 \%$ & $\mathrm{~T}$ \\
$3 \quad \begin{array}{l}\text { Menginginkan serangan hama berkurang pada sistem } \\
\text { tajarwo? }\end{array}$ & 94 & 31.33 & $80.34 \%$ & $\mathrm{~T}$ \\
$\begin{array}{l}\text { Membutuhkan tenaga kerja dalam budidaya padi sawah } \\
\text { sistem tajarwo? }\end{array}$ & 82 & 27.33 & $70.09 \%$ & $\mathrm{KT}$ \\
$\begin{array}{l}\text { Membutuhkan alat tranplanter untuk penanaman benih } \\
\text { padi sawah sistem tajarwo? }\end{array}$ & 103 & 34.33 & $88.03 \%$ & $\mathrm{~T}$ \\
\hline Jumlah & 467 & 155.67 & $399.15 \%$ & $\mathrm{~T}$ \\
\hline Rerata & 46.7 & 15.57 & $79.83 \%$ & $\mathrm{~T}$ \\
\hline
\end{tabular}

Sumber : Olah Data Primer 2019

Berdasarkan Tabel 8 capaian aspek Komponen kebutuhan dapat dilihat bahwa dari beberapa penyataan atau indikator tersebut, ternyata $80 \%$ pertanyaan dijawab dengan Kategori tepat, sedangkan 20\% pertanyaan dijawab dengan kategori kurang tepat, dengan Capaian keseluruhan dari rata- rata Komponen kebutuhan yaitu 79,83\% dengan kategori tepat. Hal ini menunjukan bahwa Kebutuhan petani terhadap sistem tanam jajar legowo cukup baik, namun masih perlu ditingkatkan dengan dilakukan penyuluhan yang berkelanjutan sehingga dapat mendorong kemauan dan 
meningkatkan persepsi petani terhadap sistem tanam jajar legowo pada kategoro sangat tepat sesuai rekomendasi. Dari hasil analisis ini menenjukan bahwa petani sangat membutuhkan teknologi tajarwo ini karena dapat meningkatkan produktivitas namun dalam penerapannya teknologi sistem tajarwo masih sangat kurang dilaksanakan/diadopsi oleh petani dilahan pertaniannya.

\section{KESIMPULAN DAN SARAN \\ Kesimpulan}

Hasil kajian mengenai persepsi petani terhadap teknologi sistem tanam jajar legowo padi sawah di Desa Tamanmartani, Kecamatan Kalasan, Kabupaten Sleman, yang telah dilakukan, maka dapat disimpulkan bahwa :

1. Berdasarkan analisis rekapitulasi persepsi petani berdasarkan 4 Komponen dalam penerapan teknologi sistem tanam jajar legowo menunjukan bahwa persepsi berdasarkan Komponen pengetahuan dengan kategori kurang tepat yaitu dengan presentase $77,01 \%$ dan dengan rata - rata 30,33, persepsi berdasarkan Komponen minat dengan kategori tepat yaitu dengan presentase $79,59 \%$ dan dengan rata - rata 24,83, persepsi berdasarkan Komponen sikap dengan kategori kurang tepat yaitu dengan prosentase $69,09 \%$ dan dengan rata - rata 26,17, persepsi berdasarkan Komponen kebutuhan dengan kategori tepat yaitu dengan prosentase 79,83\% dan dengan rata - rata 15,57.

2. Berdasarkan hasil analisis persepsi petani dari 4 Komponen mengenai; pengetahuan, minat, sikap, dan kebutuhan, ternyata Komponen paling rendah dengan presentase 67,09 yaitu Komponen sikap, dengan dipengaruhi oleh pernyataan yang terendah yaitu mengenai "penerapan penanaman sistem tajarwo" dengan presentase $58,97 \%$.

\section{Saran}

Berdasar hasil kajian ini, maka saran yang dapat disampaikan adalah :

1. Dari 4 aspek Komponen persepsi petani terhadap teknologi sistem tanam jajar legowo penulis menyarankan sebagai materi penyuluhan yaitu aspek sikap dengan capaian rata-rata 26,17 , persentase $67,09 \%$ dengan kategori kurang tepat.

2. Sebagai bahan materi penyuluhan yaitu melakukan penerapan penanaman teknologi sistem tajarwo dengan rerata 23, dan dengan persentase 58,97\% dengan kategori kurang tepat. jadi peran penyuluh sangat penting untuk memberikan informasi.

3. Tetap dilakukan penelitian lanjutan tentang persepsi petani terhadap teknologi sistem tanam jajar legowo sehingga kesejahteraan petani semakin terwujud dan memenuhi kebutuhan petani.

\section{DAFTAR PUSTAKA}

Abdul. S. 2013. Persepsi Petani Terhadap Sistem Tanam Jajar Legowo Di Lahan Rawa Lebak Kabupaten Hulu Sungai Utara Kalimantan Selatan. Seminar Nasional Inovasi Teknologi Pertanian. Hal 255

Arifin. H. S., I, Fuadi., E, Kuswarno. 2017. Analisis Faktor Yang Mempengaruhi Persepsi Mahasiswa Untirta Terhadap Keberadaan Perda Syariah Di Kota Serang. Jurnal Penelitian Komunikasi dan Opini Publik Vol. 
21 No.1, Juli: 88-101. Hal 90

Badan Penelitian dan Pengembangan Pertanian. 2016. Pedoman Umum PTT Padi Sawah. Bogor. Hal 9

Benyamin Joi Rana. 2014. Sekilas Definisi, Konsep Petani Dan Pertanian. https://organichcs.com/2014/01/10/ sekilas-definisi-konsep-petani-danpertanian/ ( diakses 16 Maret 2019)

BPS Kabupaten Sleman, 2018. Sleman Dalam Angka 2018. BPS Kabupaten Sleman.

BP3K Kecamatan Kalasan. 2018. Programa Penyuluhan Pertanian Pangan Kelautan dan Perikanan. Kecamatan Kalasan.

Gazali, S. 2018. Persepsi Petani Terhadap Teknologi Sistem Tanam Jajar Legowo Pada Budidaya Padi Sawah. Karya Ilmiah Penulisan Akhir Untuk Memperoleh Derajat Sarjana Sains Terapan Dalam Bidang Penyuluhan Pertanian. STPP Yogyakarta

Ikhwan. 2013. Peningkatan Produksi Padi Melalui Penerapan Jarak Tanam Legowo. ( Puslitbang di Bogor ). IPTEK Tanaman Pangan. Vol 8 (2): 2013. Hal 74

Kementerian Pertanian, 2013. Sistem Tanam Jajar Legowo. Hal 6

Kementerian Pertanian, 2013. Sistem tanam padi jajar legowo . Balai Pengkajian Teknologi Pertanian ( BPTP) Jambi. Hal 2

Nazir, M. 2014. Metode Penelitian. Ghalia Indonesia. Jakarta. Hal 43
Purwatiningsih, R. 2008. Persepsi Masyarakat Terhadap Peranan Puskesmas. Fakultas Ilmu Sosial Dan Ilmu Politik Universitas Sebelas Maret Surakarta. Hal 9

Rakhmat, J. 2018. Psikologi Komunikasi (Edisi Revisi).PT. Remaja Rosdakarya Offset. Bandung. Hal 63

Riduwan. 2005. Belajar Mudah Penelitian Untuk Guru, Kariawan dan Pemula. Alfabeta. Bandung. Hal 65.

Sari, F.P, 2015. Persepsi Masyarakat Pengguna Badan Penyelenggara Jaminan Sosial (Bpjs) Kesehatan Mandiri Dalam Pelayanan Rsud Lubuk Basung Kabupaten Agam. Jom FISIP Volume 2 No. 2 - Oktober 2015. Fakultas Ilmu Sosial Dan Ilmu Politik Universitas Riau, Pekanbaru. Hal 5

Simbolon, M. 2008. Persepsi dan kepribadian. Jurnal Ekonomi dan Bisnis, Volume 2, Nomor I, Maret 2008. Hal 58

Sugiyono,2018. Metode Penelitian Kuantitatif, Kualitatif Dan R\&D. Alfabeta. Bandung. Hal 145

Walgito, B. 1989 .Pengantar Psikologi sosial. Andi Offset. Yogyakarta. Hal 53.

Walgito, B. 2005. Pengantar Psikologi social (Edisi Revisi). Andi Offset. Yogyakarta. Hal 100

Wikipedia. 2019. Petani. https://id.wikipedia. org/wiki/Petani. (diakses 16 Maret 2019) 